\title{
Dekolorisasi Pewarna Tosca Menggunakan Koagulan Ferro-Sulfat dan Lumpur Aktif dari Pabrik Teksil di Salatiga pada Kondisi Aerob
}

\author{
Agustien Sri Noerwahjuํㅜ, V. Irene Meitiniarti ${ }^{1}$, dan Sri Kasmiyati ${ }^{1}$ \\ ${ }^{1}$ Fakultas Biologi, Universitas Kristen Satya Wacana; e-mail: $\underline{\text { irene.meitiniarti@uksw.edu }}$
}

\begin{abstract}
ABSTRAK
Industri tekstil mengeluarkan air limbah dengan kualitas COD, padatan tersuspensi, warna yang relatif buruk dan mengandung logam berat yang bergantung pada zat warna yang digunakan. Saat ini Perda Prop Jawa Tengah no 5 tahun 2012, belum mengatur parameter warna sebagai parameter uji namun limbah berwarna harus tetap diolah karena menyangkut masalah estetika. Salah satu pewarna yang sulit didegradasikan melalui pengolahan biologi maupun kimia/fisika adalah pewarna Turquise Blue atau Tosca. Penelitian ini bertujuan untuk mempelajari pengurangan absorbansi warna, kandungan COD dan TSS pada limbah tekstil sintetik yang mengandung pewarna tosca dengan penambahan ferro-sulfat dan lumpur aktif pada waktu tinggal tertentu dengan proses aerob. Penelitian ini menggunakan limbah cair sintetik yang mengandung pewarna tosca dengan konsentrasi warna yang sama dengan warna air limbah aslinya (absorbansi warna diukur pada $0536 \mathrm{~nm}$ ). Pengolahan dilakukan dengan mengkombinasikan proses Ferro-sulfat dan lumpur aktif pada kondisi aerob dengan sistem Sequencing Bacth Reactor (curah berurutan). Pengambilan sampel dilakukan pada jam ke 48, dan jam ke 72. Parameter yang diamati adalah absorbansi warna, COD dan TSS. Efisiensi pengurangan parameter tersebut dibandingkan pada semua perlakuan. Dari hasil penelitian dapat disimpulkan bahwa pemberian koagulan yang dikombinasi dengan lumpur aktif dapat memperbaiki kualitas air limbah. Walaupun kombinasi perlakuan ini belum menghasilkan nilai COD dan TSS yang sesuai baku mutu air limbah tekstil, namun dapat menghasilkan penurunan nilai COD, TSS, dan absorbansi warna, berturut-turut sebesar 79, 60, dan 52\% pada pengolahan jam ke 72 .
\end{abstract}

Kata kunci: Pewarna Tosca, Ferrosulfat, Lumpur Aktif, Aerob, Waktu Tinggal

\begin{abstract}
The textile industry releases waste water with COD, suspended solids, and colors qualities which are relatively poor and contain heavy metals that depend on the dyes used. Currently PP No. 5/2012 of Central Java Province, has not set color parameters as test parameters but colored waste must be processed because it involves aesthetic problems. One of dye that is difficult to degrade through biological or chemical/ physical processing is the Turquise Blue or Tosca dye. This study aims to study the reduction of color absorbance, COD and TSS content in synthetic textile wastes containing Tosca dyes with the addition of ferrosulfate and activated sludge at certain residence times with aerobic processes. This study uses synthetic liquid waste containing Tosca dyes with a concentration of color that is the same as the color of the original wastewater (color absorbance measured at $536 \mathrm{~nm}$ ). Processing is done by combining the Ferro-sulfate process and activated sludge in aerobic conditions with the Sequencing Bacth Reactor System. Sampling was carried out at 48 hours, and 72 hours. The parameters observed were color absorbance, COD and TSS. From the results of this study it can be concluded that the provision of coagulants combined with activated sludge can improve the quality of wastewater. Although this combination of treatments has not produced COD and TSS values that are in line with textile wastewater quality standards, but it can reduce the COD and TSS values, and the color absorbance of 79,60 , and $52 \%$, at 72 hours processing, respectively.
\end{abstract}

Keywords: Tosca Dyes, Ferro-Sulfate, Activated Sludge, Aerobic, Residence Time

Citation: Noerwahju, AS., Meitiniarti, VI., dan Kasmiyati, S. (2019). Dekolorisasi Pewarna Tosca Menggunakan Koagulan Ferro -Sulfat dan Lumpur Aktif dari Pabrik Teksil di Salatiga pada Kondisi Aerob. Jurnal Ilmu Lingkungan, 17(3), 500-506, doi:10.14710/jil.17.3.500-506

\section{Latar Belakang}

Seiring dengan pertumbuhan penduduk yang semakin pesat maka terjadi juga peningkatan kebutuhan pokok berupa sandang atau pakaian. Sandang atau pakaian umumnya diproduksi secara masal dari suatu industri tekstil. Oleh karena itu industri tekstil mengalami pertumbuhan yang cukup signifikan. Peningkatan produksi tekstil pada suatu negara akan memberikan peningkatan pada negara 500 tersebut, sehingga industri tekstil menjadi objek vital pada perkembangan setiap negara (Holkar et al, 2016).

Untuk menambah keindahan pada tekstil digunakan zat pewarna yang dapat berasal dari zat warna alami dan zat warna kimiawi. Penggunaan pewarna untuk produksi dengan kapasitas yang besar, umumnya dipilih zat warna kimiawi yang lebih mudah penggunaannya dan tahan lama. Proses 
pewarnaan pada bahan tekstil ada dua macam yaitu, Dyeing (Pencelupan) dan Printing (Pencapan) (Puspo, 2009). Hasil dari proses-proses tersebut pasti akan menghasilkan limbah cair yang mengandung sisa pewarna. Limbah cair yang mengandung sisa pewarna kimia ini, bila tidak diolah terlebih dahulu akan menimbulkan pencemaran pada lingkungan (Manurung, 2004; Laksono, 2012).

Zat warna tekstil yang dipakai untuk penelitian ini adalah Turquoise Blue/Tosca yang merupakan turunan senyawa sulfonat. Diketahui bahwa gugus sulfonat sangat sulit didegradasi dan membutuhkan waktu yang lama (Christina et al, 2007). Pewarna Tosca umumnya digunakan untuk pewarnaan seragam dokter dan paramedis diruang operasi. Rumus kimia dari Turquoise Blue adalah $\mathrm{C}_{41} \mathrm{H}_{25} \mathrm{ClCuN}_{14} \mathrm{Na}_{4} \mathrm{O}_{14} \mathrm{~S}_{5}$, sedangkan struktur kimianya dapat dilihat pada gambar 1 di bawah ini.

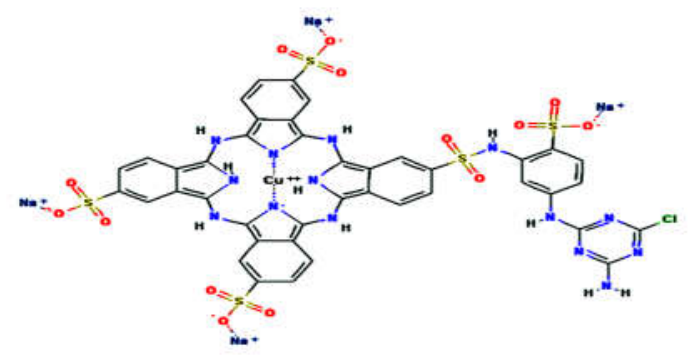

Gambar 1 Struktur kimia dari Turquise Blue/ Tosca (National Center for Biotechnology Information. NCBI, 2013).

Berdasarkan struktur kimia nya, warna tosca ini merupakan senyawa aromatik polisiklik yang mengandung senyawa Sulfonat dan cincin benzenoid polisiklik. Efek samping dari keberadaan senyawa sulfonat ini bila melebihi kapasitas degradasi alami adalah tercemarnya lingkungan akibat kerusakan komponen ekosistem karena terhambatnya pertumbuhan bakteri (terutama bakteri aerobik) tertentu di pengolahan limbah (Sanchez et al, 2008). Jika pertumbuhan bakteri dalam pengolahan limbah terhambat, maka unit pengolahan limbah tidak dapat berperan sebagai sistem pengendalian kualitas kimia dan biologi air buangan yang akan memasuki ekosistem perairan.

Selain itu, adanya gugus sulfonat dan cincin aromatik naftol pada molekul pewarna Turquise/Tosca dapat menyebabkan iritasi (Marrakchi and Maibach, 2006) dan bersifat karsinogenik (Geier et al, 2003). Oleh karena struktur kimia dari pewarna Tosca inilah yang kemungkinan menyebabkan pewarna Tosca sulit diolah dengan cara yang sederhana. Pada praktiknya di IPAL industri tekstil, air limbah yang mengandung sisa pewarna Tosca tidak dapat langsung diolah dengan lumpur aktif (komunikasi pribadi). Air limbah yang mengandung Tosca membutuhkan proses pengolahan yang lebih lama (limbah harus disiklus beberapa kali) dan tidak dapat digabung dengan air limbah lainnya.
Mengingat air limbah yang mengandung pewarna Tosca sulit didegradasi dan tidak dapat diolah langsung secara biologi, maka perlu dilakukan penelitian pengolahan limbah yang mengandung pewarna Tosca dengan mengombinasikan perlakuan kimia/fisik dan pengolahan biologi. Ferro sulfat terbukti efektif digunakan sebagai koagulan dibanding tawas dan ferri klorida (Wartiono dan Rosyida, 2011) dalam pengolahan limbah cair tekstil. Moertinah dkk (2010) mengombinasikan karbon aktif dan lumpur aktif dalam pengolahan limbah industri tekstil. Belum ada informasi terkait penggunaan koagulan ferro sulfat yang dikombinasi dengan lumpur aktif untuk mengolah limbah industri tekstil. Diharapkan dengan adanya penelitian ini dapat diketahui efektivitas penggunaan kombinasi koagulan ferro sulfat dan proses lumpur aktif dalam pengurangan absorbansi warna, kandungan COD dan TSS pada limbah tekstil sintetik yang mengandung pewarna tosca.

\section{Bahan dan Metode Penelitian 2.1 Bahan}

Bahan koagulan yang digunakan adalah kombinasi $\mathrm{FeSO}_{4}$ dan larutan kapur dengan konsentrasi berturut-turut 10\%, 20\% dan 30\% (untuk larutan $\mathrm{FeSO}_{4}$ ) dan 5\%, 10\% dan 15\% (untuk larutan kapur). Lumpur aktif yang digunakan berasal dari Unit Pengolahan Limbah (UPL) salah satu pabrik tekstil di Salatiga dan digunakan dalam pengolahan biologi dengan konsentrasi 20\% dan 30\%.

\subsection{Metode}

Penelitian yang dilakukan merupakan penelitian eksperimental-laboratoris, dimana penelitian dilakukan dalam skala laboratorium dengan limbah sintetik yang mengandung pewarna Tosca dengan konsentrasi yang disesuaikan dengan limbah aslinya.

\subsubsection{Persiapan air limbah.}

Ke dalam $1000 \mathrm{ml}$ aquades dilarutkan 5 gram pewarna Tosca (absorbansi diamati pada $\lambda 536 \mathrm{~nm}$ ). Konsentrasi ini memberikan nilai absorbansi yang sama dengan air limbah di lapang (UPL Industri tekstil). Kemudian air limbah ditempatkan dalam akuarium volume $2000 \mathrm{ml}$ untuk diproses dengan koagulasi dan dilanjutkan dengan lumpur aktif teraerasi. Sebelum diproses, dilakukan pengukuran karakteristik limbah awal meliputi absorbansi warna, kadar COD dan TSS.

\subsubsection{Proses koagulasi-flokulasi.}

Ke dalam air limbah ditambahkan $\mathrm{FeSO}_{4}$ dan $\mathrm{CaCO}_{3}$ sebagai koagulan (disebut perlakuan A). Dosis $\mathrm{FeSO}_{4}$ dan $\mathrm{CaCO}_{3}$ yang digunakan berturut-turut adalah 1) $10 \%$ dan $5 \%$, 2) $20 \%$ dan $10 \%$, dan 3) $30 \%$ dan $15 \%$. Setelah itu dilakukan proses pengadukan lambat (60 rpm selama 10 menit) dan dilanjutkan dengan proses pengendapan. Air limbah dipisahkan dari endapan/flok yang terbentuk dengan disaring menggunakan kertas saring. Sampel hasil koagulasi 
dan pengendapan ini diuji absorbansi warna, COD, TSS, sisa Ferro, dan sisa Sulfat.

\subsubsection{Proses biologi dengan lumpur aktif.}

Sebelum digunakan dalam penelitian, lumpur aktif dicuci terlebih dahulu dengan air selama 1 minggu agar bersih dan tidak terkontaminasi dengan zat lain yang tidak diperlukan, selanjutnya diaklimatisasi dengan penambahan urea, fosfat dan gula sebagai nutrisi untuk bakteri yang ada dalam lumpur aktif tersebut. Pemberian nutrisi dilakukan selama 1 minggu. Setelah diaklimatisasi, lumpur telah aktif dan siap untuk digunakan dalam proses perlakuan.

Sampel dari proses pengendapan, kemudian diproses dengan sistem biologi menggunakan Lumpur aktif (perlakuan B). Konsentrasi lumpur aktif yang digunakan adalah 0\%, 20\% dan 30\%. Proses pengolahan biologi dilakukan secara curah selama 72 jam. Pengambilan sampel dilakukan pada jam ke0, jam ke 48 dan jam ke 72. Sampel dari proses pengolahan dengan lumpur aktif diukur absorbansi warna, COD dan TSS.

Kombinasi proses pengolahan dalam penelitian ini (berupa proses koagulasi dan lumpur aktif) total sebanyak 12 perlakuan, masing-masing perlakuan diulang sebanyak 4 kali, ditunjukkan pada Tabel 1.

Tabel 1. Kombinasi perlakuan koagulasi dan lumpur aktif yang digunakan dalam penelitian ini

\begin{tabular}{cccc}
\hline KOAGUL & \multicolumn{3}{c}{ LUMPUR AKTIF } \\
\cline { 2 - 4 } AN & B 0 & B 1 & B 2 \\
\hline A 0 & A0 B0 & A0 B1 & A0 B2 \\
A 1 & A1 B0 & A1 B1 & A1 B2 \\
A 2 & A2 B0 & A2 B1 & A2B2 \\
A 3 & A3 B0 & A3 B1 & A3B2 \\
\hline
\end{tabular}

Keterangan

Ao = tanpa koagulan (kontrol), A1 = koagulan konsentrasi $10 \%$,

$\mathrm{A} 2=$ koagulan konsentrasi $20 \%$, A3 = koagulan konsentrasi $30 \%$

Bo = tanpa lumpur aktif (kontrol), B1 = Lumpur aktif konsentrasi $20 \%$

B2 = lumpur aktif konsentrasi 30\%

\subsubsection{Analisis sampel dan data}

Analisis untuk mengukur absorbansi warna, sisa $\mathrm{Fe}^{2+}$ dan sisa $\mathrm{SO}_{4}$ dilakukan secara spektrofotometri. Analisis sisa $\mathrm{Fe}^{2+}$ dilakukan secara spektrofotometri, pada $\lambda 510 \mathrm{~nm}$. Uji sisa sulfat dilakukan dengan metode kekeruhan dengan spektrofotometer pada $\lambda 420 \mathrm{~nm}$ (Underwood, 2006). Pengukuran kadar ferro dan sulfat sisa dilakukan mengunakan kit dari peralatan $\mathrm{HACH}$. Analisis COD dengan menggunakan titrimetri dan dipanaskan dengan COD reaktor, analisis TSS dengan metode pemanasan cawan petri (Effendi, 2003).

Analisis efisiensi proses dilakukan dengan membandingkan konsentrasi awal masing-masing parameter dengan konsentrasi setelah proses pengolahan. Efisiensi dihitung dengan rumus sebagai berikut:

\section{Keterangan:}

$$
E=\frac{C o-C a}{C a} \times 100 \%
$$

Ca : konsentrasi setelah perlakuan (mg/l)

Co : konsentrasi sebelum perlakuan $(\mathrm{mg} / \mathrm{l})$

E : efisiensi (\%)

Data efisiensi penurunan COD, TSS dan absorbansi warna dianalisis dengan metode Pareto. Analisis ini berfungsi untuk mengetahui faktor yang paling berpengaruh signifikan di antara perlakuan penambahan koagulan, penambahan lumpur aktif, atau kombinasi dari kedua perlakuan tersebut, dengan waktu retensi yang diamati. Metode ini dilakukan dengan mengolah data rata-rata efisiensi penurunan COD, TSS, dan absorbansi warna dari ulangan perlakuan sebanyak 4 kali.

\section{Hasil dan Pembahasan \\ 3.1 Proses Koagulasi dengan Ferro Sulfat}

Dari hasil pengolahan dengan koagulan ferrosulfat diperoleh bahwa makin besar konsentrasi koagulan ferro sulfat yang ditambahkan, makin besar penurunan konsentrasi COD, TSS dan absorbansi warna. Koagulan yang digunakan untuk proses koagulasi biasanya bermuatan positif, karena ion-ion yang terdapat dalam air limbah umumnya bermuatan negatif. Penetralan muatan tersebut mengakibatkan gaya tolak menolak antar partikel polutan hilang. Dengan hilangnya gaya tolak menolak antar partikel polutan, gaya kohesi akan bekerja menghasilkan partikel-partikel berukuran lebih besar dan dikenal sebagai flok (Hammer, 2015).

Berdasarkan penelitian Aguilar et al. (2001), flokulasi dengan ferro-sulfat ini lebih baik dengan penambahan larutan kapur dengan perbandingan 2:1. Dengan adanya bikarbonat, ferro-sulfat akan membentuk $\mathrm{Fe}(\mathrm{OH})_{2}$ yang sedikit larut dalam air, karena koagulan ferro sulfat membutuhkan suasana alkali dalam bentuk ion hidroksida, agar memacu reaksi. Dalam reaksi ini, ion $\mathrm{Fe}(\mathrm{OH})_{2}$ akan terbentuk lebih banyak dan mengendap. Dengan menambahkan larutan kapur $\mathrm{Ca}\left(\mathrm{HCO}_{3}\right)_{2}$ diharapkan akan memberikan ion hidroksida lebih banyak dan dapat mengikat zat warna yang terbentuk sehingga partikel menjadi lebih besar.

$\mathrm{FeSO}_{4}+\mathrm{Ca}\left(\mathrm{HCO}_{3}\right)_{2} \rightarrow \mathrm{Fe}(\mathrm{OH})_{2}+\mathrm{CaSO}_{4} \downarrow+2 \mathrm{CO}_{2}$

$\mathrm{FeSO}_{4}+\mathrm{Ca}(\mathrm{OH})_{2}+2 \mathrm{CO}_{2} \rightarrow \mathrm{Fe}(\mathrm{OH})_{2}+\mathrm{CaSO}_{4} \downarrow$

Ion hidroksida $\left(\mathrm{OH}^{-}\right)$akan meningkatkan $\mathrm{pH}$ air limbah sehingga akan memicu oksidasi $\mathrm{Fe}^{2+}$ di dalam air membentuk ion bermuatan positif menjadi $\mathrm{Fe}^{3+}$. Ion ini memiliki kemampuan untuk menyerap permukaan partikel-partikel tersuspensi yang bermuatan negatif (Liang et al, 2014). Hal ini memungkinkan terjadinya penyerapan warna tosca yang bermuatan negatif, sehingga warna tosca menjadi berkurang.

$\mathrm{Fe}^{3+}+3 \mathrm{Tosca}$ (tereduksi) $+\mathrm{OH}-\rightarrow$ Fetosca(teroksidasi) ${ }_{3}+3 \mathrm{H}_{2} \mathrm{O}$ 
Satu molekul $\mathrm{Fe}^{3+}$ akan mengikat tiga molekul tosca yang tereduksi menjadi Fe-(tosca) 3 . Hal ini menyebabkan penurunan konsentrasi COD, TSS dan absorbansi warna dalam air limbah, seperti terlihat pada Gambar 2, 3 dan 4.

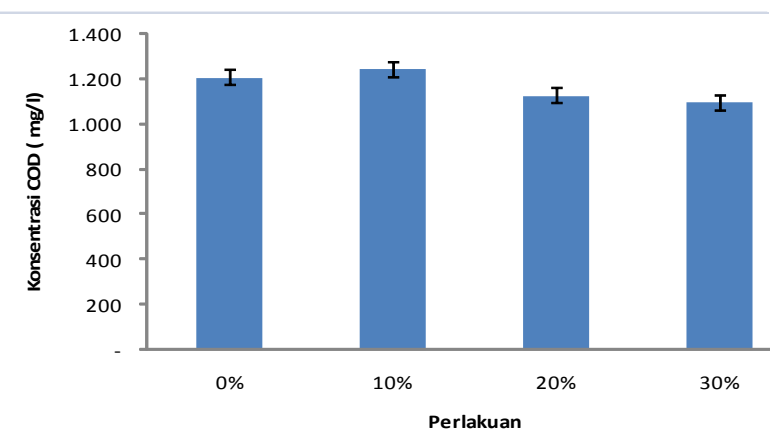

Gambar 2. Konsentrasi COD pada sampel setelah proses $\mathrm{FeSO}_{4}$ dengan $0 \%, 10 \%, 20 \%$, dan $30 \%$

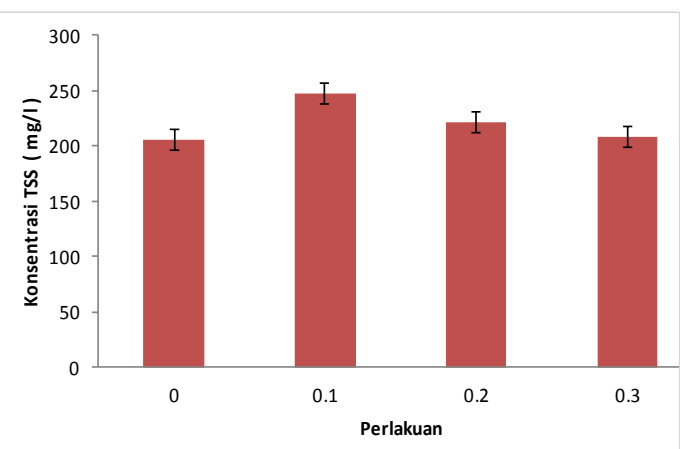

Gambar 3. Konsentrasi TSS pada proses koagulasi dengan $0 \%, 10 \%, 20 \%$, dan $30 \%$

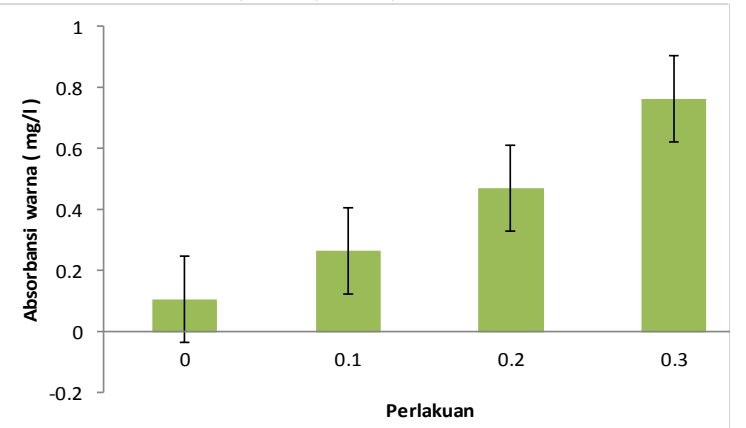

Gambar 4. Konsentrasi Absorbansi warna pada Proses Koagulasi dengan 0\%, 10\%, 20\% dan 30\%

Semakin banyak massa koagulan yang masuk, maka akan terjadi kenaikan konsentrasi kesetimbangan ion ferro. Nilai konsentrasi $\mathrm{Fe}^{2+}$ terendah terjadi pada perlakuan $0 \%$ (kontrol), yang menunjukkan bahwa pada air dan pewarna saja telah mempunyai konsentrasi $\mathrm{Fe}^{2+} 0,2 \mathrm{mg} / \mathrm{l}$. Hal ini sesuai penelitian Rump and Krist (2000), bahwa kadar besi dalam air yang mendapat cukup aerasi (aerob) hampir tidak pernah lebih dari $0,3 \mathrm{mg} / \mathrm{l}$. Sedangkan nilai maksimal terjadi pada perlakuan $30 \%$ koagulan, yaitu sebesar $1,62 \mathrm{mg} / \mathrm{l}$. Semakin banyak massa koagulan yang masuk, maka akan terjadi kenaikan konsentrasi kesetimbangan ion ferro. Analisis data $\mathrm{SO}_{4}$ juga menunjukkan hal yang sama, yaitu nilai konsentrasi terendah terjadi pada perlakuan $0 \%$ (kontrol), yaitu mempunyai konsentrasi 2,5 mg/l, dan nilai tertinggi pada perlakuan 30\% koagulan, seperti terlihat pada Gambar 5. Hal ini menunjukkan bahwa penggunaan koagulan harus melihat efektifitasnya, jika terlalu banyak koagulan yang diberikan, selain biaya menjadi tinggi tetapi juga ada sisi negatifnya yaitu bau limbah menjadi anyir (amis).

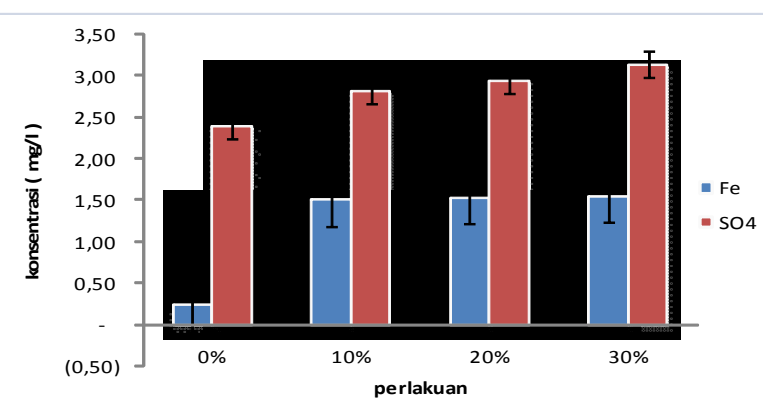

Gambar 5. Sisa $\mathrm{Fe}$ dan $\mathrm{SO}_{4}$ yang ada dalam larutan setelah proses koagulasi

\subsection{Proses dengan lumpur aktif pada kondisi aerob}

Hasil analisis kandungan COD, TSS dan absorbansi warna keluaran dari pengolahan biologi dengan lumpur aktif menunjukkan bahwa semakin besar konsentrasi lumpur aktif yang digunakan, semakin besar kandungan COD, TSS dan absorbansi warnanya. Demikian pula dengan waktu yang digunakan. Semakin lama waktu yang digunakan semakin kecil konsentrasi COD, TSS dan absorbansi warna. Berdasarkan struktur kimia pewarna Tosca yang tergolong senyawa organik, keberadaan senyawa Tosca dalam medium/limbah sintetik ini memberikan nilai konsentrasi COD. Walaupun berdasarkan struktur kimianya, pewarna Tosca sulit didegradasi, tetapi hasil penelitian menunjukkan bahwa senyawa Tosca mungkin digunakan sebagai sumber $\mathrm{C}$ dan $\mathrm{N}$ oleh mikroba dalam lumpur aktif. Penelitian Pakou et al. (2007) membuktikan bahwa senyawa alkilbensen sulfonat (seperti pewarna Tosca) dapat dimineralisasi dengan lengkap oleh mikrob aerob. Kemungkinan penggunaan senyawa pewarna tersebut sebagai sumber bahan organik menyebabkan nilai konsentrasi COD menjadi turun. Demikian juga dengan TSS. Penurunan konsentrasi Total Suspended Solid (TSS) disebabkan bakteri telah mengurai padatan yang terkandung pada pewarna tosca. Makin lama waktu yang dipakai makin besar penurunan konsentrasi TSS nya.Hal ini sesuai dengan penelitian Irvan et al. (2012) yang menyatakan bahwa bakteri akan mengurai padatan yang terkandung dalam limbah dan mengubahnya menjadi zat makanan, menyebabkan nilai TSS menurun seiring dengan bertambahnya waktu tinggal. Gambar 7 dan 8 menunjukkan penurunan nilai konsentrasi COD dan TSS setelah proses lumpur aktif dan waktu tinggal yang berbeda $(0,48$, dan 72 jam).

Penurunan konsentrasi pewarna ini kemungkinan karena bakteri aerob dalam lumpur aktif menggunakan karbon dan nitrogen dari pewarna yang ada di dalam air limbah sebagai sumber karbon 
dan nitrogen untuk kelangsungan hidupnya sehingga molekul pewarna yang kompleks berubah menjadi molekul sederhana berupa $\mathrm{CO}_{2}, \mathrm{H}_{2} \mathrm{O}, \mathrm{NH}_{3}$ dan biomassa (Hammer, 2015). Terjadinya peruraian pewarna dan perubahan senyawa pewarna menjadi lebih sederhana (menjadi $\mathrm{CO}_{2}$ dan $\mathrm{NH}_{3}$ ), selain akan menyebabkan dekolorisasi (pemudaran/penurunan absorbansi warna), juga akan menyebabkan TSS dan konsentrasi COD menurun.

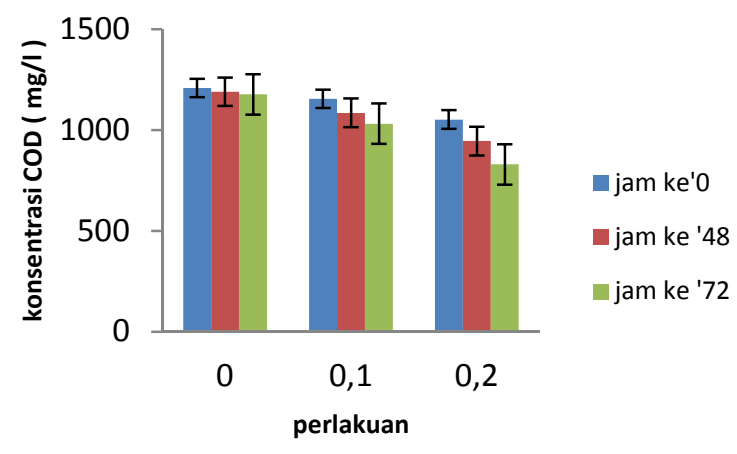

Gambar 7. Konsentrasi COD pada Proses Lumpur Aktif dengan $0 \%, 10 \%$ dan $20 \%$

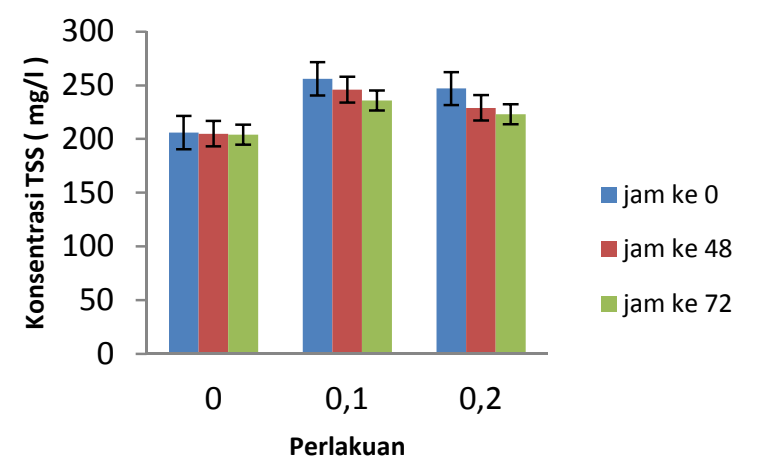

Gambar 8. Konsentrasi TSS pada Proses Lumpur Aktif dengan $0 \%, 10 \%$ dan $20 \%$

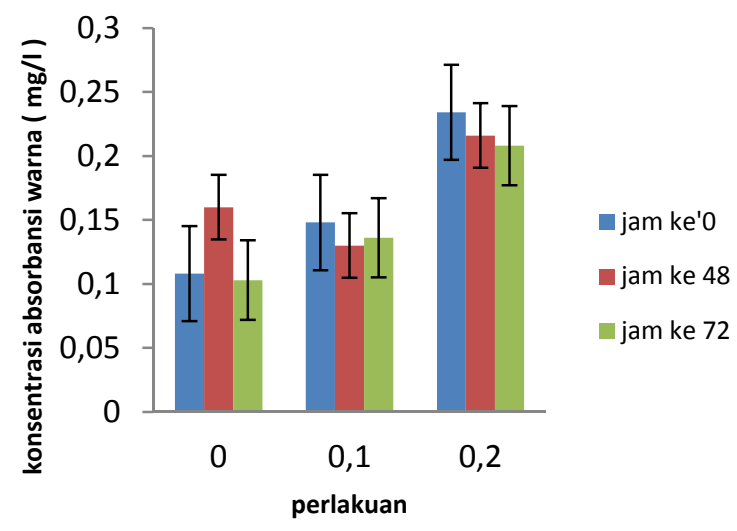

Gambar 9. Konsentrasi Absorbansi Warna pada Proses Lumpur Aktif dengan 0\%, 10\% dan 20\%

\subsection{Efisiensi Penurunan COD, TSS dan absorbansi warna pada perlakuan kombinasi koagulan dan lumpur aktif}

Adanya perlakuan penambahan koagulan dan lumpur aktif berpengaruh sangat nyata dalam memperbaiki kualitas air limbah.
Dari hasil pengamatan pada semua perlakuan dan waktu pengamatan, nilai efisiensi penurunan COD, TSS, dan absorbansi warna berbanding lurus dengan konsentrasi dari masing-masing perlakuan. Artinya makin besar penambahan koagulan dan lumpur aktif yang digunakan dalam proses, efisiensi penurunan pada COD, TSS dan Absorbansi warna semakin besar. Demikian juga dengan waktu yang semakin lama (72 jam) maka efisiensi penurunan parameter juga semakin besar (Tabel 2). Dari analisa data penelitian yang didapat, dengan konsentrasi koagulan 30\%, lumpur aktif $20 \%$, dan waktu 72 jam menunjukkan efisiensi penurunan COD, TSS dan Absorbansi warna terbesar masing-masing 79\%, 60\% dan 52\%.

Tabel 2. Efisiensi pengurangan COD, TSS dan absorbansi warna pada perlakukan koagulan dan lumpur aktif.

\begin{tabular}{|c|c|c|c|c|c|c|}
\hline \multirow[t]{2}{*}{ Perlakuan } & \multicolumn{2}{|c|}{$\begin{array}{c}\text { Efisiensi pe- } \\
\text { ngurangan } \\
\text { COD }(\%)\end{array}$} & \multicolumn{2}{|c|}{$\begin{array}{c}\text { Efisiensi pe- } \\
\text { ngurangan } \\
\text { TSS (\%) }\end{array}$} & \multicolumn{2}{|c|}{$\begin{array}{l}\text { Efisiensi pe- } \\
\text { ngurangan } \\
\text { Ab.warna (\%) }\end{array}$} \\
\hline & $\begin{array}{c}48 \\
\text { jam }\end{array}$ & $\begin{array}{c}72 \\
\text { jam }\end{array}$ & $\begin{array}{c}48 \\
\text { jam }\end{array}$ & $\begin{array}{c}72 \\
\text { jam }\end{array}$ & 48 jam & $\begin{array}{c}72 \\
\text { jam }\end{array}$ \\
\hline A0B0 & 1.50 & 2.82 & 0.36 & 0.97 & (47.35) & 4.62 \\
\hline A0B1 & 6.09 & 10.69 & 4.2 & 7.94 & 5.47 & 8.14 \\
\hline A0B2 & 10.17 & 21.14 & 7.26 & 11.12 & 7.50 & 10.85 \\
\hline A1B0 & 4.14 & 7.82 & 3.14 & 6.57 & 4.37 & 9.65 \\
\hline A1B1 & 11.83 & 19.78 & 6.82 & 12.55 & 10.53 & 17.01 \\
\hline A1B2 & 25.94 & 39.49 & 22.46 & 27.56 & 15.50 & 21.30 \\
\hline A2B0 & 5.84 & 12.16 & 6.66 & 19.59 & 14.94 & 16.65 \\
\hline A2B1 & 18.11 & 34.12 & 19.49 & 28.45 & 19.71 & 22.55 \\
\hline $\mathrm{A} 2 \mathrm{~B} 2$ & 37.86 & 55.66 & 30.55 & 48.28 & 23.97 & 43.87 \\
\hline A3B0 & 7.16 & 19.16 & 17.27 & 26.93 & 22.34 & 24.66 \\
\hline A3B1 & 29.90 & 38.07 & 30.15 & 37.54 & 30.92 & 47.12 \\
\hline A3B2 & 50.84 & 79.11 & 40.66 & 59.87 & 44.80 & 52.23 \\
\hline
\end{tabular}

Pada konsentrasi koagulan yang kurang dari 30\%, konsentrasi lumpur aktif kurang dari 20\% dan waktu kurang dari 72 jam, efisiensi penurunan COD di bawah $56 \%$. Hal ini terjadi karena dengan kombinasi konsentrasi koagulan dan lumpur aktif yang sesuai akan terjadi efisiensi penurunan COD yang maksimal. Hasil ini berdasarkan penelitian Sigit (2004), mikroba yang terkandung dalam lumpur aktif bekerja mengurangi kandungan bahan organik dalam air limbah melalui proses enzimatis (oksidasi) maupun non-enzimatis (adsorbsi) sehingga terjadi penurunan kandungan COD. Bakteri aerobik memerlukan oksigen dalam mengoksidasi senyawa organik untuk memperoleh energi yang digunakan untuk pertumbuhan dan multiplikasi sel (Gambar 10).

Sedangkan untuk TSS terjadi efisiensi penurunan terbesar 60\%. Jika konsentrasi koagulan kurang dari $30 \%$, konsentrasi lumpur aktif kurang dari $20 \%$ dan waktu kurang dari 72 jam, efisiensi penurunan TSS di bawah 50\%. Hal ini terjadi karena partikel-partikel zat padat tersuspensi yang ada dalam pewarna tosca terikat oleh proses koagulasi sehingga membentuk flok yang mengendap secara gravitasi. Waktu tinggal dan dosis koagulan yang tepat membantu proses 
pengendapan secara sempurna ditunjukkan pada Gambar 11.

Hasil analisis data penelitian, penurunan absorbansi warna yang didapat terbesar adalah 52\%. Jika konsentrasi koagulan kurang dari 30\%, konsentrasi lumpur aktif kurang dari $20 \%$ dan waktu kurang dari 72 jam, efisiensi penurunan absorbansi warna di bawah 45\%. Hal ini terjadi karena adanya penambahan $\mathrm{Fe}^{2+}$ dan Larutan kapur yang dapat meningkatkan penurunan nilai warna. Radikal hidroksil (ROOH) yang terbentuk karena adanya reaksi $\left(\mathrm{OH}^{-}\right)$akan menghancurkan molekul-molekul pewarna yang ada dalam zat warna menjadi lebih kecil selanjutnya bakteri yang ada dalam lumpur aktif akan mengurai padatan yang berupa molekul pewarna menjadi zat makanan, seiring dengan bertambahnya waktu tinggal semakin banyak zat makanan yang dipergunakan oleh bakteri sehingga menyebabkan efisiensi dekolorisasi menjadi besar (Gambar 12).

Kombinasi perlakuan antara koagulan dan lumpur aktif harus diberikan secara bersama-sama karena jika hanya perlakuan koagulan saja, efisiensi penurunan nilai TSS maupun absorbansi warna masing-masing hanya sebesar $27 \%$ dan 25\%. Jika hanya perlakuan lumpur aktif saja, efisien penurunan nilai TSS dan absorbansi warna, masing-masing sebesar $11 \%$ dan 12\%. Khusus COD dari analisis Pareto, tampak bahwa lumpur aktif berperan penting dalam efisiensi penurunan karena tanpa lumpur aktif tidak terjadi penurunan COD (Gambar 10).

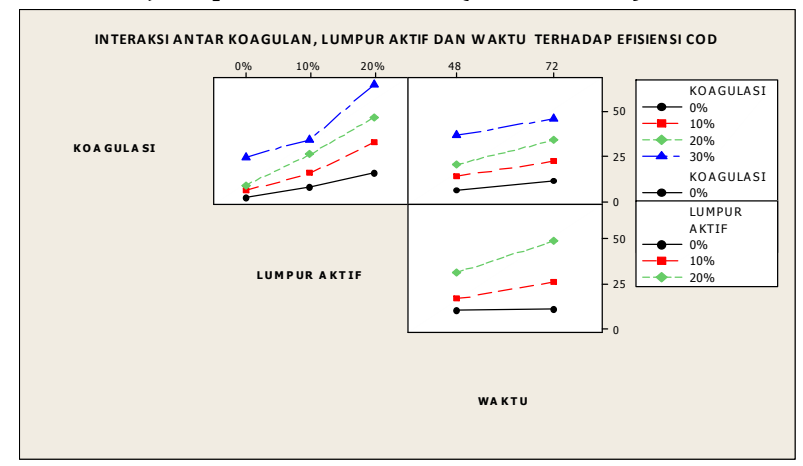

Gambar 10. Interaksi koagulan, lumpur aktif dan waktu terhadap efisiensi penurunan COD

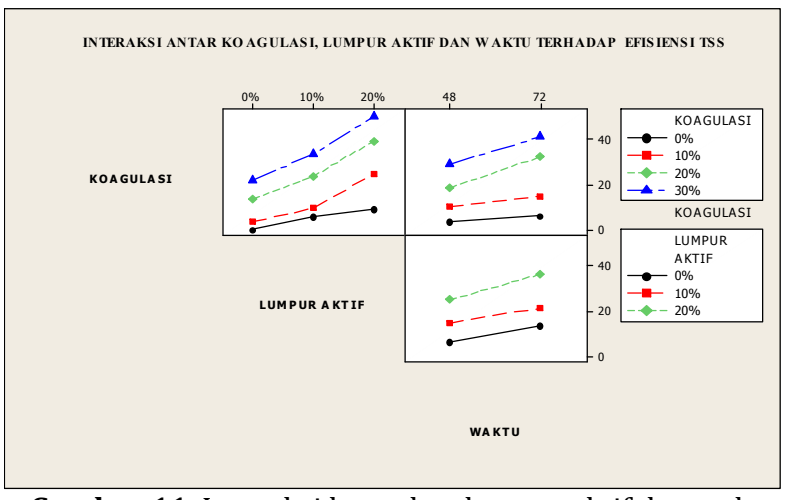

Gambar 11. Interaksi koagulan, lumpur aktif dan waktu terhadap efisiensi penurunan TSS

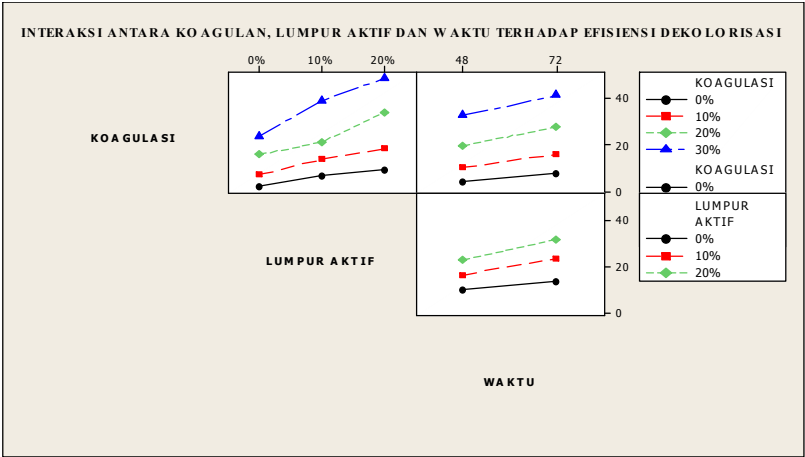

Gambar 12. Interaksi koagulan, lumpur aktif dan waktu terhadap efisiensi absorbansi warna

Walaupun secara keseluruhan gabungan proses (koagulasi-flokulasi dan lumpur aktif) dapat memperbaiki kualitas air limbah yang mengandung pewarna Tosca (maksimum 79\%), namun pemberian ke 2 perlakuan ini, belum berhasil memperbaiki kualitas air limbah hingga sesuai baku mutu (Permen LHK P.16/MENLHK/SETJEN/KUM.1/4/2019), yaitu nilai COD dan TSS 150 dan $50 \mathrm{mg} / \mathrm{l}$. Selain itu, lumpur hasil proses koagulasi-flokulasi masih memerlukan proses pengolahan lebih lanjut karena merupakan lumpur kimia (B3). Perlu penelitian lebih lanjut dengan menggunakan senyawa kimia lain atau karbon aktif untuk menggantikan koagulan agar proses penghilangan warna dan COD lebih efektif dan tidak menghasilkan lumpur kimia. Moertinah dkk (2010) menggunakan karbon aktif yang dimasukkan langsung dalam sistem lumpur aktif dan terbukti efektif menurunkan kadar warna indigo dan sulfur. Dapat juga dicoba penggunaan bakteri Enterococcus faecalis ID6017 dan Chryseobacterium indologenes ID6016 yang terbukti dapat mendegradasi pewarna azo (Meitiniarti dkk. 2012).

\section{Kesimpulan}

Dari perlakuan yang diujikan didapat efisiensi penurunan COD, TSS, dan absorbansi warna terbaik adalah pada konsentrasi koagulasi 30\%, lumpur aktif $20 \%$ dan pada jam ke 72 , yaitu berturut-turut sebesar $79 \%, 60 \%$, dan $52 \%$.

\section{UCAPAN TERIMAKASIH}

Pada kesempatan ini, penulis menyampaikan ucapan terimakasih kepada semua pihak, terutama pihak Industri tekstil di Salatiga dan laboratorium Fakultas Biologi UKSW, yang telah membantu dalam pengunaan sampel pewarna dan lumpur aktif, serta penggunaan sarana laboratorium, hingga selesainya penelitian ini.

\section{DAFTAR PUSTAKA}

Aguilar MI, Saez J, Llorens M, Soler A, Ortuno JF (2001). Microscopic Observation of Particle Reduction in Slaughterhouse Wastewater by CoagulationFlocculation Using Ferric Sulphate as Coagulant and Different Coagulant Aids, Water research 37 (9): 2233-2241.

Christina MP, Mu'nisatun S, Saptaaji R, Maranto D. (2007). Studi Pendahuluan Mengenai Degradasi Zat Warna 
Azo Dalam Pelarut Air Menggunakan Mesin Berkas Elektron $350 \mathrm{KEV} / 10 \mathrm{~mA}$, Jurnal Forum Nuklir 1 (1): 31-44.

Efendi H. (2003). Telaah Kwalitas Air bagi Pengelolaan Sumber Daya dan Lingkungan Perairan. Ed 5. Kanisius. Yogjakarta.

Holkar CR, Jadhav AJ, Pinjani DV, Nahumuni NM, Pandit AB. 2016. A Critical Review on Textile Wastewater Treatments: Possible Approaches. Journal of Environmental Management 182: 351-366.

Geier J, Uter W, Pirker C, Frosch PJ. (2003). Patch Testing with the Irritant Sodium Lauryl Sulfat (SLS) is useful in Interpreting weak Reaction. Journal Contac Dermatitis, 4: 99-107.

Hammer MJ. 2004. Water and Waste Water Technology.

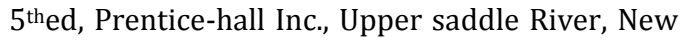
Jersey

Irvan BT, Vincent M, Tendean Y. (2012). Pengolahan limbah cair kelapa sawit secara aerobik menggunakan efektif mikroorganisme guna mengurangi TSS. Jurnal Teknik Kimia USU 1: 27 - 30

Khopkar SM. (2008). Basic Concepts of Analytical Chemistry. Penerjemah Saptorahardjo, A. Konsep Dasar Kimia Analitik. Penerbit Universitas Indonesia.Jakarta.

Laksono S. (2012). Pengolahan Biologis Limbah Batik dengan Media Biofiler. Teknik Lingkungan UI. Depok

Liang CZ, Sun SP, Li FY, Ong YK, Chung TS. (2014). Treatment of Highly Concentrated Wastewater Containing Multiple Synthetic Dyes by Combined Process of Coagulation/Flocculation \& Nanofiltration. Journal of Membrane Science 469: 306 - 315.

Manurung R. (2004). Perombakan zat warna Azo Reaktif secara anaerob dan aerob. e-USU Repository 2004. Universitas Sumatera Utara. HIm 1-19

Marrakchi S, Maibach HI. (2006). Sodium Lauryl SulfatInduced Irritation in the Human Face. Regional and age -related D Physiol differences. Journal Skin Pharmacology and Physiology 19(3): 66.

Meitiniarti VI, Timotius KH, Soetarto ES, Sugiharto E. (2012). Decolorization of Orange II by mixed culture of $E$. faecalis ID6017 and C. indologenes ID6016. J. Microbiol. Indones: 117-123.
Moertinah S, Djarwanti, Sartamtomo, Yuliastuti R, Yuliasni R. (2010). Peningkatan kinerja lumpur aktif dengan penambahan karbon aktif dalam pengolahan air limbah industri tekstil pewarnaan dengan zat warna indigo dan sulfur. Jurnal Riset Industri Vol IV No 1: 23-33

NCBI. (2013). Toxicology Browser, Turqiese Blue (online) https://pubchem.ncbi.nlm.nih.gov. Diakses tanggal 20 Pebruari 2013.

Pakou C, Stamatelatou K, Kornaros M, Lyberatos G. (2007). On the complete aerobic microbial mineralization of linear alkylbenzene sulfonate. Desalination 215:198-208.

PermenLHK P.16/MENLHK/SETJEN/KUM.1/4/2019. Baku mutu air limbah industri tekstil.

Puspo G. (2009). Pemilihan Bahan Tekstil. Kanisius. Yogyakarta

Rump, Krist HH. (2000). Laboratory Manual for Examination

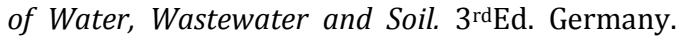
Weinheim.

Sanchez-Peinado MM, Gonzalez-Lopez J, Rodelas B, Galera V, Pozo C, Martinez-Toledo MV. (2008). Effect of Linear Alkylnenzene Sulfonate on the Growth of Aerobic Heteroprophic Cultivable Bacteria Isolated From an Agricultural Soil. Ecotoxicology 17 (6): 549-557.

Schleheck D, Knepper TP, Fischer K, Cook AM. (2004). Mineralization of Individual Congener of Linier Alkylbenzene Sulfonate by Defined Pairs of Heterotrophic Bacteria. Applied \& Environmental Microbiology 70 (7): 4053-4063

Sigit H. (2004). BOD dan COD Sebagai Parameter Pencemaran Air dan Baku Mutu Air Limbah, Bogor, IPB

Underwood AL, Junior DRA. (2006). Analisis Kimia Kuantitatif, $6^{\text {th }}$ Ed., Erlangga, Jakarta

Wartiono T, Rosyida A. (2011). Pemilihan tawas, ferri khlorida dan ferro sulfat sebagai zat koagulan yang paling efektif dalam pengolahan limbah cair tekstil. Jurnal Teknika ATW Edisi 6 No 3: 1-10. 